\title{
SISTEM PEMASARAN GAMBIR DI SUMATERA BARAT (Kasus di Kecamatan Kapur IX, Kabupaten Lima Puluh Kota)
}

\author{
Amelira Haris Nasution ${ }^{1)}$, Ratna Winandi Asmarantaka ${ }^{2)}$ dan Lukman M Baga ${ }^{3)}$ \\ ${ }^{1)}$ Mahasiswa Pascasarjana Magister Sains Agribisnis, FEM, Institut Pertanian Bogor \\ ${ }^{2)}$ Staf Pengajar Departemen Agribisnis, FEM, Institut Pertanian Bogor \\ ${ }^{3)}$ Staf Pengajar Departemen Agribisnis, FEM, Institut Pertanian Bogor \\ Email: liranasution@gmail.com
}

\begin{abstract}
Gambier is one of the commodity export in Indonesia and it has been supplied $80 \%$ of the world's needs. The largest gambier production area is Lima Puluh Kota Regency, West Sumatera (70,39\%). The benefit from its position as the biggest gambier supplier or producer is not enjoyed by gambier farmer because of weak gambier marketing and the role of merchand middlement had a more powerful and dominant for determine of gambier prices. The purpose of this study is analyzing marketing system of gambier through marketing channel analysis, marketing channel's role analysis (farmer group and merchand middlemen) and operational efficiency analysis. This study was conducted from Desember 2014 until January 2015 in Kapur IX Subdistrict, Lima Puluh Kota Regency, West Sumatera. Farmers were chosen by purposive sampling method and middlemen were chosen by snowball sampling method. Data processing in this study was using descriptive qualitative and quantitative analysis. The result of this study showed that there are 4 marketing channels of gambier marketing. Based on operational efficiency indicator, all marketing channels had been inefficiency because of weak farmer's bargaining power so their role is just as a price taker. But among all marketing channels, channel 4 is more efficient relatively based on benefit and cost ratio, price share and marketing function implementation. The result of this study also showed that farmer group and farmer association of gambier are still in starter institution so that they are not capable to contribute in marketing gambier.
\end{abstract}

Keywords : Efficiency, Gambier, Marketing

Abstrak : Gambir adalah komoditas ekspor Indonesia dan memasok $80 \%$ kebutuhan
dunia. Daerah produksi terbesar gambir adalah Kabupaten Lima Puluh Kota, Sumatera
Barat (70,39\%). Keuntungan dari posisinya sebagai pemasok atau produsen terbesar
gambir tidak dinikmati oleh petani gambir akibat lemahnya pemasaran gambir dan
peran lembaga pemasaran relatif lebih kuat dan dominan dalam menentukan harga jika
dibandingkan dengan petani. Penelitian ini bertujuan menganalisis sistem pemasaran
gambir melalui analisis saluran pemasaran, peran lembaga pemasaran (kelompok tani
dan perantara) serta efisisensi operasional. Penelitian ini dilakukan pada bulan
Desember 2014 hingga Januari 2015 di Kecamatan Kapur IX, Kabupaten Lima Puluh
Kota, Sumatera Barat. Petani dipilih dengan metode purposive sampling dan snowball
sampling untuk perantara.Pengolahan data dalam penelitian ini menggunakan analisis
deskriptif kualitatif dan kuantitatif. Hasil penelitian menunjukkan terdapat 4 saluran
dalam pemasaran gambir. Berdasarkan indikator analisis efisiensi operasional
menunjukkan bahwa saluran pemasaran (1, 2, 3 dan 4) yang terbentuk belum efisien
akibat posisi tawar petani yang rendah sehingga petani hanya berperan sebagai
penerima harga. Akan tetapi diantara seluruh saluran pemasaran, saluran 4 merupakan
saluran yang relatif lebih efisien berdasarkan rasio keuntungan dan biaya serta share
harga dan pelaksanaan fungsi-fungsi pemasaran. Hasil penelitian ini juga 
menunjukkan bahwa kelompok tani dan asosiasi petani gambir masih berada pada kelas kelompok pemula sehingga belum mampu berkontribusi dalam bidang pemasaran gambir.

Kata kunci : Efisiensi, Gambir, Pemasaran

\section{PENDAHULUAN}

Gambir adalah komoditas ekspor Indonesia yang diperoleh dari proses pengempaan tanaman Uncaria gambier (Hunt.) Roxb. Ekstrak gambir mengandung Katekin dan Tanin yang berguna sebagai bahan baku industri farmasi, kosmetik, penyamakan kulit, pewarna, dan industri makanan.

Indonesia menempati posisi yang sangat penting sebagai produsen gambir terbesar di dunia dengan memasok $80 \%$ kebutuhan gambir dunia (Sa'id et al. 2009; Adi 2011; BAPPENAS dan GIZ 2013). Berdasarkan data Trade Map tahun 2014 dengan HS 320190100 Gambier dan 3201901000 Gambier, trend perkembangan ekspor gambir cenderung meningkat dengan 17 negara tujuan ekspor.

Sumatera Barat merupakan sentra gambir terbesar di Indonesia dan mampu memasok $80 \%$ hingga $90 \%$ dari total produksi gambir nasional (Ermiati 2004; Sa'id et al. 2009; Sa'id 2010) dengan Kabupaten Lima Puluh Kota sebagai penghasil terbesar gambir (70.39\%).

Dengan posisi sebagai negara penghasil terbesar gambir dunia, Indonesia diharapkan mampu meningkatkan kesejahteraan dan taraf hidup petani gambir karena keunggulan yang relatif lebih tinggi dari negara lain dalam hal produksi gambir. Akan tetapi, harapan normatif tersebut tidak dirasakan dalam realitanya. Adanya paradoks posisi gambir Indonesia yang mendunia, justru tidak dinikmati oleh petani gambir Indonesia. Hal ini diduga akibat lemahnya sistem pemasaran gambir serta kurangnya peran kelembagaan (dalam hal ini organisasi gambir) dalam bidang pemasaran gambir, sehingga diduga sistem pemasaran gambir belum efisien.

Tujuan dari penelitian ini adalah menganalisis sistem pemasaran gambir melalui analisis saluran pemasaran, peran lembaga pemasaran (organisasi gambir dan pedagang perantara) serta analisis efisiensi operasional untuk mengetahui sejauhmana efisiensi sistem pemasaran gambir dan peran lembaga pemasaran di Kabupaten Lima Puluh Kota.

\section{METODE PENELITIAN}

Penelitian dilakukan di Kecamatan Kapur IX , Kabupaten Lima Puluh Kota, Sumatera Barat. Pengambilan data dilaksanakan pada bulan Desember 2014 hingga Januari 2015.

Metode pengambilan contoh petani dilakukan dengan purposive sampling dengan jumlah 31 orang. Kriteria petani gambir yang menjadi sampel adalah petani telah melakukan proses pengempaan dan menghasilkan gambir siap dijual. Sedangkan pengambilan contoh untuk pedagang dilakukan dengan snowball sampling berdasarkan alur pemasaran yang ada di Kabupaten Lima Puluh Kota. Jumlah responden untuk pedagang adalah 12 orang.

Pengolahan data menggunakan analisis deskriptif kualitatif untuk menganalisis saluran pemasaran gambir serta peran lembaga pemasaran gambir dan analisis kuantitatif untuk mengukur efisiensi operasional melalui margin pemasaran dan farmer share.

\section{Analisis Margin Pemasaran}

Margin pemasaran merupakan kumpulan jasajasa pemasaran sebagai akibat adanya aktivitas produktif atau konsep nilai tambah (value added) (Kohl dan Uhl 2002). Rumus yang dapat digunakan untuk mengukur margin pemasaran adalah:

$M T=\operatorname{Pr}-P f=$ Biaya $^{2}+\pi$ Lembaga $=\Sigma M i$

$M i=P_{j i}-P_{b i}$

\section{Dimana:}

MT = Margin Total

$\mathrm{Mi}=$ Marjin di tingkat lembaga ke $\mathrm{i}$, dimana $\mathrm{i}=1,2, \ldots, \mathrm{n}$

Pr = Harga di tingkat konsumen akhir

$\mathrm{Pf} \quad=$ Harga di tingkat produsen

$\pi$ lembaga $=$ Profit lembaga pemasaran akibat adanya sistem pemasaran

$\mathrm{Pji}=$ Harga penjualan untuk lembaga pemasaran ke-i

$\mathrm{Pbi}=$ Harga pembelian untuk lembaga pemasaran ke-i 


\section{Analisis Farmer's Share}

Farmer's share merupakan porsi dari harga yang dibayarkan konsumen akhir terhadap petani dalam bentuk persentase. Rumus yang digunakan dalam menghitung farmer's share adalah:

$$
F^{*} s=\left\{\frac{P f}{P r}\right\} X 100 \%
$$

Dimana:

$$
\begin{aligned}
\text { F's }= & \text { Farmer's Share } \\
\mathrm{Pf}= & \text { Harga ditingkat produsen } \\
\mathrm{Pr} & =\text { Harga ditingkat retail (tingkat } \\
& \text { konsumen akhir) }
\end{aligned}
$$

\section{HASIL DAN PEMBAHASAN}

\section{Pasar dan Pemasaran}

Pemasaran gambir dilakukan setiap minggu selama musim panen oleh petani. Tujuannya untuk memperoleh uang yang dapat digunakan untuk menutupi pengeluaran dalam pengolahan gambir serta kebutuhan keluarga.

Salah satu yang membedakan Kecamatan Kapur IX dengan kecamatan penghasil gambir lainnya di Kabupaten Lima Puluh Kota terletak pada lokasi transaksi penjualan gambir. Kegiatan transaksi penjualan dan pembelian gambir dilakukan di pasar sesuai dengan hari pasar masing-masing nagari. Transaksi penjualan di pasar diatur oleh pemerintah nagari dengan adanya Natura. di lokasi pasar gambir. Natura adalah memiliki fungsi sebagai pencatat transaksi hasil penjualan gambir petani dan melalukan penarikan sejenis retribusi yang digunakan untuk kas nagari. Besarnya retribusi yang harus dikeluarkan adalah $0.01 \%$ dari hasil penjualan gambir (setiap transaksi penjualan Rp 1.000.000,- dikenai natura Rp 10.000,-).

\section{Karakteristik Responden}

1. Karakteristik petani

Karakteristik petani diidentifikasi berdasarkan faktor yang berpengaruh terhadap pengembangan usahatani gambir seperti umur, pendidikan, pengalaman usahatani, dan luas lahan gambir yang dikelola.

Berdasarkan Tabel 1, sebanyak 45,16\% petani gambir berada pada usia produktif yaitu 23 tahun hingga 39 tahun. Pada usia produktif, kecendrungan petani untuk menerima pengetahuan baru akan lebih baik dibandingkan dengan usia non produktif karena pola pikir dan nalar yang cenderung dinamis.

Pola pikir ini juga berhubungan dengan tingkat pendidikan. Pendidikan yang relatif lebih tinggi dan umur yang muda membuat petani mampu berpikir secara dinamis dan bertindak secara rasional. Sehingga dengan

Tabel 1. Identitas petani responden

\begin{tabular}{lll}
\hline No & Karakteristik Petani Responden & Petani $\mathrm{n}=31$ \\
\hline 1 & Umur (Tahun) & \\
& $23-39$ & $14(45,16)$ \\
& $40-54$ & $10(32,26)$ \\
& $>55$ & $7(22,58)$ \\
\hline 2 & Tingkat Pendidikan & \\
& Tidak Tamat SD & $2(6,45)$ \\
& SD & $12(38,71)$ \\
& SMP & $8(25,81)$ \\
& SMA & $9(29,03)$ \\
\hline 5 & Pengalaman Usaha Tani (Tahun) & \\
& $<10$ & $6(19,35)$ \\
& $10-20$ & $13(41,94)$ \\
& $>20$ & $12(38,71)$ \\
\hline 4 & Luas Lahan Petani (Ha) & \\
& 0,5 & $13(3,23)$ \\
& 1 & $3(9,68)$ \\
& $1,5-2,0$ & $16(51,61)$ \\
& $>2,0$ & $11(35,48)$ \\
\hline
\end{tabular}

Data primer (2015), diolah 
rata-rata pendidikan yang rendah $(38,71 \%)$ tentu saja akan memberikan dampak pada cara petani dalam menyikapi perubahan dan dalam kasus ini berkaitan dengan penanganan hasil produksi gambirnya.

Petani responden dalam penelitian ini telah memiliki pengalaman berusahatani gambir selama 10 hingga 20 tahun $(41,94 \%)$. Pengalaman berusahatani akan berpengaruh terhadap teknik pengelolaan dalam pemeliharaan dan pengolah usahatani gambir. Petani yang memiliki pengalaman yang lebih lama akan cenderung mengelola dengan mengacu pada pengalamannya selama berusahatani.

Luas lahan gambir yang dimiliki petani berkisar antara 1,5 ha hingga 2 ha $(51,61 \%)$. Menurut Tohir (1991), dengan kriteria luas lahan tersebut petani gambir dapat disebut sebagai petani yang mampu memenuhi kebutuhan hidup melalui kegiatan usahatani gambir. Namun berdasarkan hasil wawancara ditemukan bahwa dengan rata-rata luas lahan yang dimiliki petani gambir, ternyata belum dapat dikatakan menguntungkan bagi petani karena sistem bagi hasil pendapatan dari penjualan gambir yang dilakukan dengan anak kampo sebagai patner dalam pengolahan atau pengempaan gambir menyebabkan penerimaan petani menjadi lebih kecil.

\section{Karakteristik pedagang}

Pedagang yang menjadi responden dalam penelitian ini terdiri atas penyalur sebanyak 1 orang, pedagang pengumpul sebanyak 4 orang, pedagang besar 4 orang dan eksportir 3 orang. Sebagian besar pedagang $(77,78 \%)$ masih berusia produktif antara 28 tahun hingga 45 tahun dengan pengalaman berdagang 2 hingga 57 tahun.

Pedagang pengumpul gambir memiliki petani yang tetap dan tidak tetap sebagai sumber pemasok gambir. Sedangkan pedagang besar selain memiliki petani tetap dan tidak tetap dalam memasok gambir, juga memiliki pedagang pengumpul tetap dan tidak tetap sebagai pemasok gambir. Petani atau pedagang pengumpul yang tetap biasanya merupakan petani atau pedagang pengumpul yang telah diberi modal terlebih dahulu oleh pedagang.

Dalam penelitian ini terdapat 3 perusahaan eksportir yang menjadi responden dengan pengalaman pedagangan internasional 10 hingga 27 tahun.

\section{Asosiasi Petani Gambir (APEGI)}

APEGI merupakan organisasi gambir yang dibentuk secara swadaya pada tanggal 3 Januari 2012. Selama kurun waktu 3 tahun ini, APEGI bergerak sebagai organisasi yang mengadvokasi petani untuk membantu meningkatkan pendapatan petani gambir serta peningkatan skill petani dalam pengolahan daun gambir. Berdasarkan hasil penelitian diketahui bahwa organisasi ini belum mampu menaungi seluruh petani gambir yang ada di Kabupaten Lima Kota akibat tersebarnya lokasi petani. Sedangkan untuk bidang pemasaran, hingga saat ini APEGI masih belum mampu untuk berkontribusi akibat peran pedagang yang lebih besar dibandingkan asosiasi dalam mencapai pelosok daerah untuk mengumpulkan dan membeli gambir dari petani. Selain itu, kondisi organisasi yang masih muda (pemula) juga menyebabkan akses terhadap pemasaran yang masih belum terbuka lebar.

Dengan kondisi ini, tentu saja sangat diharapkan peran pemerintah dalam mendukung keberadaaan asosiasi ini. Posisi asosiasi sebagai kelembagaan gambir yang memiliki fokus pada kesejahteraan petani gambir tentu saja akan lebih mudah berkembang bila pemerintah mampu menetapkan kebijakan yang bisa memposisikan asosiasi sebagai wadah pemersatu petani gambir dalam meningkatkan bargaining power petani gambir.

\section{Kluster Harau}

Kluster Harau merupakan organisasi yang dibentuk oleh kelompok kerja Kabupaten Lima Puluh Kota (anggota SKPD, akademisi, LSM, eksportir, lembaga keuangan dan petani) pada Desember 2014 dan bergerak dalam pengembangan gambir. Kluster Harau dibentuk sebagai percontohan lembaga atau organisasi yang bergerak dalam pengembangan gambir dengan tujuan untuk memperkuat posisi gambir sebagai komoditas unggulan Kabupaten Lima Puluh Kota. Sistem Kluster ini dianggap menjanjikan karena beranggotakan pelaku usaha dan produsen gambir. Sehingga diharapkan mampu menjadi wadah dalam pengembangan gambir kedepannya. 
Berdasarkan hasil penelitian dengan ketua Kluster Harau diketahui bahwa untuk saat ini Kluster Harau masih berada pada tahap awal organisasi. Hingga wawancara terakhir dengan (Desember 2014) diketahui bahwa kegiatan Kluster Harau hanya berupa beberapa kali pertemuan untuk pembentukan rencana Kluster Harau kedepannya. Sehingga peran Kluster Harau belum dapat dirasakan dalam pengembangan gambir khususnya dalam bidang pemasaran dan manfaat dari adanya organisasi Kluster Harau belum dirasakan oleh petani gambir.

\section{Kelompok Tani}

Berdasarkan data dari BAPPEDA (2013), terdapat 102 kelompok tani yang menjadikan gambir sebagai salah satu komoditi unggulannya dan tersebar di 5 Kecamatan di Kabupaten Lima Puluh Kota. Dari data tersebut juga diketahui bahwa terdapat 56 kelompok tani di Kecamatan Kapur IX yang tersebar di 6 kenagarian. Hasil penelitian menunjukkan bahwa dari 2 responden kelompok tani diketahui bahwa peran kelompok tani tehadap anggotanya masih terbatas pada kegiatan on farm dan pengolahan. Sedangkan untuk kegiatan pemasaran ditemukan adaya ketergantungan yang kuat antara petani anggota dengan pedagang akibat belum mampunya kelompok tani untuk berkontribusi dalam bidang pemasaran gambir. Kendala utama yang dihadapi kelompok berkaitandengan modal dan kemampuan dalam melakukan pemasaran gambir yang cenderung sulit akibat tertutupnya pasar gambir.

\section{Analisis Saluran Pemasaran Gambir di Kecamatan Kapur IX}

Lembaga pemasaran seperti petani, penyalur, pedagang pengumpul, pedagang besar dan eksportir memiliki berbagai macam alternatif pilihan dalam menyalurkan gambir. Terdapat 5 macam saluran pemasaran di Kecamatan Kapur IX yaitu :

Saluran 1 : Petani-penyalur-pedagang besareksportir lokal

Saluran 2 : Petani-pedagang pengumpulpedagang besar-eksportir lokal

Saluran 3 : Petani-pedagang pengumpulekportir lokal

Saluran 4 : Petani-pedagang besar-ekspotir lokal

Saluran 5 : Petani-pedagang besar-eksportir luar dan pedagangbesar di Pulau Jawa

Dari Gambar 1 dapat dilihat bahwa sebagian besar petani memilih untuk melakukan penjualan gambir kepada pedagang pengumpul. Hal ini dapat dilihat dari persentase penjualan petani pada saluran 2 dan saluran 3 sebesar $54.84 \%$. Sedangkan sisanya lebih memilih untuk melakukan penjualan kepada penyalur maupun pedagang besar.

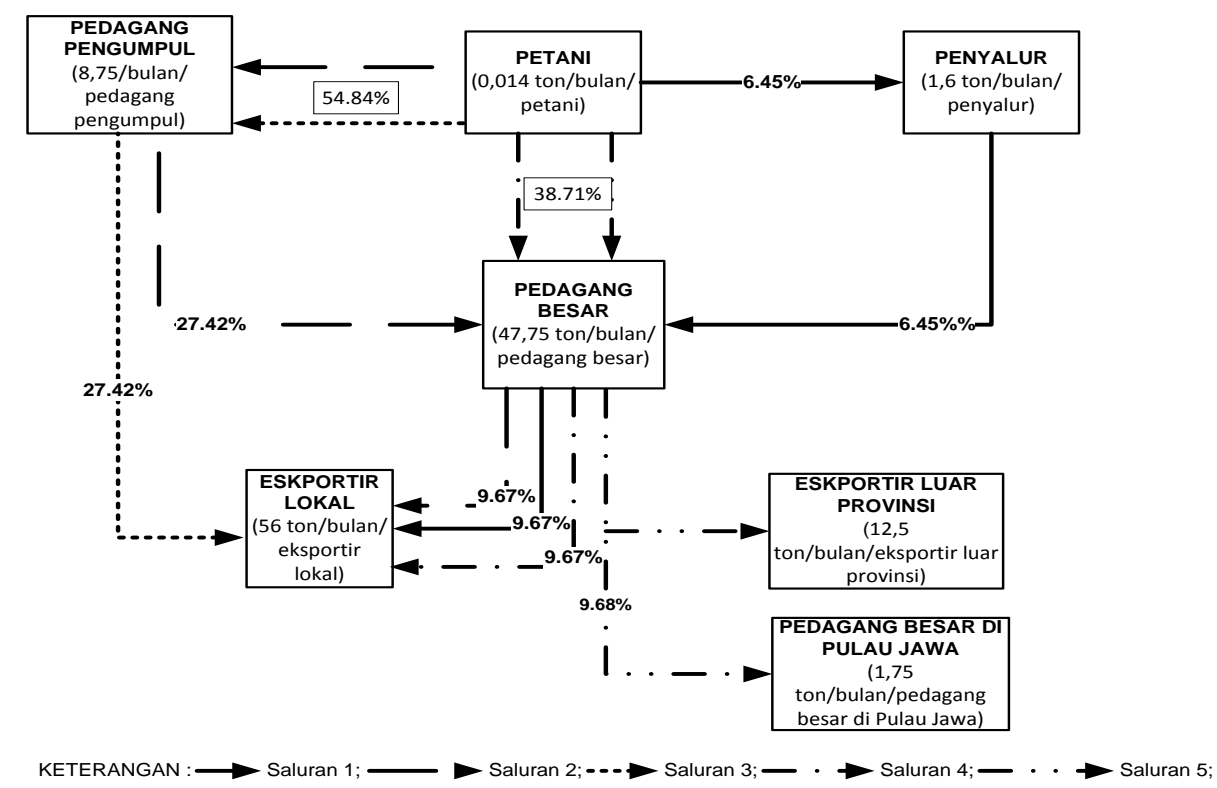

Gambar 1. Saluran pemasaran di Kecamatan Kapur IX 
Untuk meningkatkan harga jual, pedagang pengumpul, pedagang besar maupun eksportir akan melakukan kegiatan penjemuran kembali. Bahkan untuk tingkat pedagang besar dan ekportir, kegiatan sortasi juga dilakukan untuk mengelompokkan gambir berdasarkan tujuan pemasaran yang berbeda-beda.

\section{Lembaga Pemasaran dan Fungsi Pemasaran}

Dalam pemasaran gambir terdapat 4 lembaga pemasaran yang terlibat, yaitu penyalur, pedagang pengumpul, pedagang besar dan eksportir dengan fungsi yang berbeda-beda dalam memberikan nilai (value). Sedangkan organisasi gambir (asosiasi petani gambir, Kluster Harau dan kelompok tani) tidak memiliki keterlibatan dalam pemasaran gambir.

\section{Peran Organisasi Gambir}

Organisasi yang bergerak untuk pengembangan komoditas gambir di Kabupaten Lima Puluh Kota mencakup Asosiasi Petani Gambir (APEGI), Kluster Harau dan kelompok tani. Berdasarkan perannya, organisasi gambir yang ada di Kabupaten Lima Puluh Kota belum bergerak kearah kegiatan penguatan posisi tawar petani melalui konstribusinya dalam bidang pemasaran gambir. Hal ini disebabkan oleh posisi organisasi gambir yang dapat dikategorikan sebagai pemula dan hanya bergerak pada on farm dan pengolahan gambir saja.

Selain itu, berdasarkan hasil wawancara juga diketahui bahwa tidak adanya organisasi kelompok tani yang fokus terhadap pengembangan komoditas gambir juga mengakibatkan posisi gambir dalam organisasi petani tidak menjadi central pengembangan sehingga kontribusi kelompok tani dalam pemasaran gambir masih sulit untuk dicapai meskipun harapan penguatan posisi tawar petani bisa ditingkatkan dengan berkelompok.

\section{Mekanisme Pembentukan Harga}

Dalam pembentukan harga gambir eksportir memiliki kontribusi yang kuat sebagai penentu harga. Dilain pihak, eksportir juga memiliki ketergantungan dari segi harga berdasarkan nilai tukar rupiah terhadap dollar, keadaan ekonomi dan regulasi pemerintah di negara tujuan ekspor serta kuantitas yang dibutuhkan ketika penandatangan kontrak dilakukan dengan buyers.

Nilai kontrak ekspor biasanya berbasis FOB (free on board), yaitu barang diatas kapal di pelabuhan eksportir. Kesepakatan harga antara eksportir dengan buyers biasanya sangat bergantung pada kondisi permintaan dan penawaran gambir. Selain itu, kesepakatan harga juga berkaitan dengan mutu gambir. Setiap gambir yang dibeli oleh eksportir akan dilakukan pengecekan kadar abu dan kadar air. Jika kadar air dan kadar abu semakin tinggi, itu artinya kualitas gambir tidak bagus.

Sebagian besar pedagang besar melakukan tawar menawar dalam penentuan harga gambir. Namun sepakat ataupun tidaknya eksportir terhadap tawar menawar tersebut biasanya tergantung pada kualitas gambir yang dijual pedagang. Sebelum kegiatan pembelian gambir kepada petani atau pedagang pengumpul, biasanya pedagang besar melakukan proses komunikasi terlebih dahulu dengan eksportir. Proses komunikasi biasanya berisi mengenai pencarian informasi harga yang berlaku saat akan dilakukan pembelian gambir atau disaat akan dilakukan pengiriman gambir ke gudang eksportir. Penetapan harga gambir yang akan dibeli eksportir dari pedagang besar maupun pedagang pengumpul biasanya juga berdasarkan kualitas gambir yang dijual pedagang.

Dari hasil wawancara dengan seluruh responden pedagang disimpulkan bahwa alur penetapan harga pertama berada pada pihak importir yang kemudian disusul oleh ekportir, pedagang besar, pedagang pengumpul dan penyalur. Pada penetapan harga ini dapat dilihat bahwa peran eksportir sebagai penentu harga tingkat lokal sangat kuat. Sehingga posisi petani dalam proses penetapan harga masih berada pada posisi price taker yang tidak memiliki kekuatan tawar menawar.

\section{Marjin Pemasaran dan Farmer Share}

Analisis marjin pemasaran gambir dan farmer share dilakukan mulai dari penyalur dan pedagang pengumpul, pedagang besar serta eksportir. Dalam analisis ini akan dilihat selisih harga beli dan harga jual dari masing-masing lembaga pemasaran yang terlibat dalam pemasaran gambir. Pada akhirnya akan dapat dilihat margin total dalam kegiatan pemasaran 
gambir yang merupakan selisih harga di tingkat petani dengan harga di tingkat eksportir.

Kecamatan Kapur IX merupakan daerah sentra produksi gambir terbesar di Kabupaten Lima Puluh Kota. Berdasarkan hasil penelitian, ditemukan ada 5 saluran pemasaran gambir yang dilakukan lembaga pemasaran. Namun yang akan dianalisis distribusi harga beli, biaya pemasaran, harga jual dan keuntungan atau sebaran marginnya hanya 4 saluran pemasaran saja. Saluran pemasaran yang kelima tidak dapat dianalisis karena saluran terputus hanya sampai pada pedagang besar. Hal ini juga berkaitan dengan batasan penelitian yang telah ditetapkan hanya berhubungan dengan lembaga pemasaran yang berada di Provinsi Sumatera Barat.

Dengan indikator total margin terkecil dan farmer share tertinggi, Tabel 2 menunjukkan bahwa saluran 4 yang terdiri dari petani, pedagang besar dan eksportir relatif lebih efisien bila dibandingkan dengan saluran lainnya. Pada saluran 4, harga ditingkat petani jauh lebih tinggi dibandingkan dengan saluran lainnya, namun total biaya pemasaran yang harus dikeluarkan lebih besar dibandingkan saluran lainnya yaitu $14.71 \%$ dari harga jual (saluran $1=13.35 \%$, saluran $2=11.44 \%$, saluran $3=12.63 \%$ ) dan persentase total keuntungan yang lebih kecil dibandingkan saluran 1 dan 2 yaitu $34.44 \%$ (saluran $1=$ $24.51 \%$, saluran $2=42.08 \%$, saluran 3 $=41.18 \%$ ). Sehingga rasio keuntungan terhadap biaya pada saluran 4, relatif lebih kecil dibandingkan saluran 1 dan 2.

Meskipun berdasarkan indikator margin dan farmer share menunjukkan saluran 4 relatif efisien, akan tetapi bila dilihat dari volume transaksi pembelian gambir dari tingkat petani menunjukkan bahwa pada saluran 4 memiliki volume transaksi pembelian dari tingkat petani yang relatif lebih besar dibandingkan saluran 1 dan 2. Sehingga hal ini menunjukkan bahwa petani cenderung lebih banyak menjual hasil produksi gambir mereka pada saluran 2 dan 3 yang menjadikan pedagang pengumpul sebagai lembaga penghubung antara tingkat petani dengan pedagang besar ataupun eksportir karena mampu menerima gambir dengan jumlah yang relatif lebih sedikit bila dibandingkan dengan menjual kepada pedagang besar.

Kesediaan pedagang pengumpul untuk membeli hasil gambir petani dalam jumlah sedikit memberikan dampak pada ketergantungan petani pada pedagang pengumpul. Dengan sifat gambir yang tidak dapat dimanfaatkan secara langsung oleh petani bila tidak dijual dan dengan tingkat kebutuhan petani untuk memenuhi kebutuhan hidupnya serta keterikan petani terhadap pedagang berupa kerjasama yang seolah-olah menguntungkan petani melalui pemberian pinjaman, menyebabkan lemahnya posisi petani sehingga petani berada pada posisi penerima harga dan menerima berapapun harga yang ditetapkan pedagang. Hal ini dapat dilihat dari harga jual ditingkat petani pada saluran 2 dan 3 yang merupakan harga terendah dibandingkan 2 saluran lainnya yaitu Rp 18 266.67.

Untuk memperkuat posisi petani maka diperlukan pembentukan dan penguatan kelompok tani, koperasi maupun asosiasi. Hal ini bertujuan untuk meningkatkan efisiensi pemasaran gambir, sehingga petani sebagai produsen gambir juga dapat menerima hasil yang seimbang dengan usaha yang dilakukannya. Disisi lain, pembentukan dan penguatan kelembagaan juga akan mengurangi

Tabel 2. Sebaran total biaya pemasaran, total keuntungan, total margin dan Rasio $\pi / \mathrm{c}$ pada masing-masing saluran di Kecamatan Kapur IX

\begin{tabular}{lllllllll}
\hline Saluran & $\begin{array}{l}\text { Harga beli } \\
\text { (petani) }\end{array}$ & $\begin{array}{l}\text { Harga jual } \\
\text { (eksportir) }\end{array}$ & $\begin{array}{l}\text { Total Biaya } \\
\text { Pemasaran }\end{array}$ & $\begin{array}{l}\text { Total } \\
\text { Keuntungan }\end{array}$ & $\begin{array}{l}\text { Total } \\
\text { Margin }\end{array}$ & $\begin{array}{l}\text { Rasio } \\
\pi / \mathrm{c}\end{array}$ & $\begin{array}{l}\text { Farmer } \\
\text { Share }\end{array}$ & $\begin{array}{l}\text { Volume/ } \\
\text { Bulan } \\
\text { (ton) }\end{array}$ \\
\hline I & 21166.67 & 32546.85 & 4345.71 & 7979.48 & 11380.18 & 1.84 & 65.03 & 0.13 \\
2 & 18266.67 & 32339.54 & 3700.52 & 13610.13 & 14072.88 & 3.68 & 56.40 & 1.41 \\
3 & 18266.67 & 32546.85 & 4113.1 & 13404.78 & 14280.18 & 3,26 & 56.12 & 1.41 \\
4 & 21925.00 & 32546.85 & 4787.91 & 11177.44 & 10621.85 & 2.33 & 67.38 & 3.18 \\
\hline
\end{tabular}

Data primer (2015), diolah 
tekanan terhadap petani dalam hal permodalan. Dengan melembaga, petani akan mampu melakukan pemasaran secara kolektif sehingga aliran modal dari pendapatan dapat dinikmati oleh petani.

\section{Efisiensi Pemasaran Gambir}

Secara umum, hasil analisis menunjukkan bahwa keempat saluran yang terbentuk dalam sistem pemasaran gambir belum efisien akibat posisi tawar petani yang rendah sehingga petani hanya berperan sebagai penerima harga. Akan tetapi diantara keempat saluran tersebut, saluran 4 merupakan saluran yang relatif efisien dibandingkan 3 saluran lainnya. Hal ini dapat dilihat dari share harga, rasio keuntungan dan biaya serta pelaksanaan fungsi-fungsi pemasaran pada saluran tersebut.

Berdasarkan 4 saluran pemasaran gambir diketahui bahwa petani hanya bertindak sebagai penerima harga (price taker) karena posisi tawar yang rendah. Kecenderungan eksportir sebagai pengendali harga untuk tingkat lokal dan kecenderungan pedagang besar, pendagang pengumpul maupun penyalur sebagai kaki tangan lembaga pemasaran diatasnya membuat posisi petani tidak dapat berubah dalam hal harga.

Posisi sebagai price taker ini juga merupakan konsekuensi struktur pasar gambir yang oligopsoni. Banyaknya jumlah petani gambir dan sedikitnya jumlah pedagang menyebabkan petani tidak memiliki kekuatan untuk meningkatkan posisi tawarnya. Akses informasi harga ditingkat eksportir/ importir yang cenderung tertutup dengan laju perubahan harga yang relatif cepat dan fluktuatif turut menimbulkan ketidakpastian bagi petani gambir sehingga tidak punya kesempatan memperoleh harga terbaik atau melakukan rebut tawar dalam transaksi penjualan.

Kecenderungan cara pikir petani untuk melakukan penjualan gambir dengan menerima berapapun harga yang ditawarkan di pasar dengan tujuan memperoleh pendapatan untuk memenuhi kebutuhan sehari-hari dan biaya anak kampo juga menjadi salah satu faktor yang menyebabkan lemahnya posisi tawar petani. Selain itu, dalam sistem pembayaran yang berlaku untuk keempat saluran pemasaran tersebut diketahui bahwa adanya ketergantungan petani terhadap modal kerja yang diberikan oleh pedagang untuk membiayai anak kampo juga mengakibatkan kecenderungan petani untuk menerima harga yang ditetapkan oleh pedagang.

Jika melihat pada struktur pasar gambir, sebenarnya terdapat celah yang bisa dimanfaatkan petani gambir untuk meningkatkan bargaining power dalam hal harga. Celah keterbatasan pedagang, bisa dimanfaatkan petani dengan membentuk lembaga pemasaran secara berkelompok. Menurut Kohl dan Uhl (2002), pembentukan lembaga dapat meningkatkan bargaining power petani melalui penetuan harga secara kolektif atau kelompok (collective bargaining approaches to pricing) seperti dengan pembentukan koperasi dan asosiasi.

Berdasarkan hasil penelitian diketahui bahwa lembaga atau organisasi yang bersinggungan dengan komoditas gambir belum mampu berperan dalam bidang pemasaran gambir. Jika dihubungkan dengan pendekatan kelembagaan dalam sistem pemasaran, lembaga pemasaran yang berperan dalam pemasaran gambir adalah pedagang perantara bukan organisasi. Hingga saat ini, organisasi petani dan asosiasi petani belum mampu berkontribusi dalam bidang pemasaran gambir. Sehingga harapan adanya lembaga yang mampu meningkatkan bargaining power petani masih belum mampu diwujudkan berdasarkan hasil penelitian ini. Posisi organisasi petani yang berada pada kelas kelompok pemula juga menyebabkan organisasi petani gambir belum mampu berekspansi dan berkontribusi dalam sitem pemasaran gambir. Oleh karena itu, peran para stakeholder terutama pemerintah sangat dibutuhkan dalam memperbaiki sistem pemasaran gambir dan meningkatkan peran kelompok tani, koperasi dan asosiasi dalam memberdayakan petani. Diharapkan dominasi pedagang perantara dalam menekan harga gambir dapat dihindari petani dengan adanya kelompok tani, koperasi dan asosiasi.

\section{Implikasi Analisis Efisiensi Pemasaran dan Peran Kelembagaan Dalam Sistem Pemasaran Gambir}

Dalam pendekatan kelembagaan pada sistem pemasaran gambir, ditemui lembaga-lembaga yang bergerak pada komoditas gambir, yaitu 
pedagang perantara, pengolah dan organisasi. Analisis fungsi pemasaran menunjukkan bahwa pada bidang pemasaran, peran pedagang perantara relatif lebih dominan dibandingkan peran organisasi petani.

Berdasarkan analisis identifikasi struktur pasar ditemukan bahwa pasar gambir mengarah kepada oligopsoni dari sisi pembeli, dengan adanya hambatan untuk keluar masuk pasar gambir. Jika dihubungkan dengan posisi Kabupaten Lima Puluh Kota sebagai penghasil terbesar gambir, seharusnya posisi penjual dalam hal ini petani bisa berada sebagai pelaku monopoli dan bisa menjadi price maker. Akan tetapi, jika dihadapkan dengan sisi pasar penjual yang oligopsoni dengan tidak adanya informasi permintaan dan tidak berlakunya sistem kuota dalam pemasaran gambir, membuat petani justru hanya bertindak sebagai price taker dengan menerima harga beli $\mathrm{Rp} 18$ 266.67 dan $\mathrm{Rp} 21$ 328.13. Hal ini diperburuk dengan kondisi organisasi petani yang masih belum mampu mengadvokasi dan berperan dalam bidang pemasaran. Sehingga dalam pemasaran gambir petani lebih cenderung memilih untuk memasarkan gambir melalui saluran yang relatif tidak efisien $(54.84 \%$ di Kecamatan Kapur IX) dengan total margin pemasaran gambir yang relatif tinggi dan share harga yang relatif rendah (total margin pemasaran $=14$ 280. 18; farmer share $=$ $56.12 \%$ ). Oleh karena itu, kecenderungan bargaining power petani gambir yang lemah masih selalu ditemukan dan diperparah dengan adanya keterikatan yang seolah saling menguntungkan antara petani dan pedagang.

Salah satu hambatan yang ditemui dalam pemasaran gambir akibat market power pedagang perantara dapat ditemukan pada pembatasan pasar gambir yang hanya menerima gambir hasil kempaan petani dalam bentuk olahan setengah jadi dengan kadar catechin yang rendah akibat pencampuran. Sedangkan untuk olahan yang lebih baik berupa gambir murni, cenderung terhambat pemasarannya dengan kecilnya pasar yang menampung hasil pengolahan tersebut serta penetapan harga gambir yang tidak memiliki perbandingan yang tinggi antara gambir kualitas bagus dan jelek (harga gambir murni berkisar antara Rp 39000 hingga Rp 40 000; dan harga gambir campuran berkisar antara Rp 18 266,67 hingga Rp 22 500). Sehingga pada akhirnya petani lebih memilih mengolah gambir dengan kualitas campuran dengan pasar sasaran yang didominasi oleh peran pedagang pengumpul sebagai perantara antar petani dengan lembaga pemasaran diatasnya. Market power ini bisa terbentuk karena adanya kerjasama yang tidak saling menguntungkan antara pedagang perantara dan petani akibat sistem pembayaran dimuka. Oleh karena itu, untuk menanggulangi hal ini sangat dibutuhkan penguatan dan pembentukan kelembagaan yang berpihak pada petani gambir seperti asosiasi, koperasi ataupun kelompok tani.

Disisi lain, sangat diharapkan peran pemerintah dalam memperbaiki sistem pemasaran gambir dan penguatan kelembagaan melalui kebijakan dan regulasi untuk meningkatkan sistem pemasaran gambir. Regulasi berupa pengendalian pasar gambir tingkat daerah sangat diperlukan untuk memperkuat posisi petani. Pengendalian pemasaran gambir dengan memanfaatkan intelejen pasar secara baik akan menghadirkan informasi yang akurat untuk memperbaiki kelemahan sistem pemasaran gambir. Sehingga diharapkan akan terciptanya pemasaran yang lebih efisien dan adil.

\section{KESIMPULAN DAN SARAN}

\section{Kesimpulan}

1. Berdasarkan indikator analisis efisiensi operasional menunjukkan bahwa saluran pemasaran $(1,2,3$, dan 3$)$ yang terbentuk belum efisien akibat posisi tawar petani yang rendah sehingga petani hanya berperan sebagai penerima harga. Akan tetapi diantara 4 saluran pemasaran tersebut, saluran 4 merupakan saluran yang relatif lebih efisien jika dilihat dari rasio keuntungan terhadap biaya, margin pemasaran, share harga yang diterima petani serta pelaksanaan fungsi pemasaran.

2. Hasil penelitian menunjukkan bahwa asosiasi petani gambir dan kelompok tani belum mampu untuk terjun dan berperan dalam bidang pemasaran gambir untuk memperkuat bargaining power petani. Lembaga pemasaran yang berperan dalam pemasaran gambir adalah pedagang perantara dan cenderung tidak berpihak pada petani 


\section{Saran}

1. Diperlukan penguatan peran organisasi yang telah ada dalam sistem pemasaran gambir untuk peningkatan efisiensi pemasaran.

2. Sangat diharapkan adanya peran pemerintah dalam meningkatkan akses petani terhadap informasi pasar dan permodalan dalam pengembangan gambir. Hal ini bertujuan untuk mengurangi kerjasama yang tidak menguntungkan petani akibat lemahnya informasi pasar dan akses modal.

\section{DAFTAR PUSTAKA}

Adi AHB. 2011. Pengembangan Agroindustri Gambir di Kabupaten Lima Puluh Kota, Sumatera Barat [Disertasi]. 2011, Institut Pertanian Bogor. Bogor.

[BAPPEDA] Badan Perencanaan dan Pembangunan Daerah Kabupaten Lima Puluh Kota. 2013. Pedoman Pengembangan (Master Plan) Gambir Kabupaten Lima Puluh Kota Tahun 2011-2015. 2013, BAPPEDA. Kabupaten Lima Puluh Kota.

[BAPPENAS; GIZ] Badan Perencanaan dan Pembangunan Nasional, Deutsche Gesellschaft für Internationale Zusammenarbeit GmbH. 2013. Studi Kelayakan Usaha Pengolahan Produk
Berbahan Baku Gambir di Kabupaten Lima Puluh Kota. 2013, BAPPENAS dan GIZ GmbH. Padang .

Ermiati. 2004. Budidaya, Pengolahan Hasil dan Kelayakan Usahatani Gambir di Kabupaten Lima Puluh Kota. Buletin TRO, Vol 15 No. 1: 50-64.

Kohls RI, Uhl JN. 2002. Marketing of Agricultural Products. Ninth Edition. 2002, Prentice Hall. New Jersey.

Sa'id EG, Syamsu K, Mardliyati E, Herryandie A, Evalia NA, Rahayu DL, Puspitarini AAAR, Ahyarudin A, Hadiwijoyo A. 2009. Agroindustri dan Bisnis Gambir Indonesia. 2009, IPB Press. Bogor.

Sa'id EG. 2010. Review Kajian, Penelitian dan Pengembangan Agroindustri Strategis Nasional: Kelapa Sawit, Kakao dan Gambir. J. Tek. Ind. Pert, Vol 19 No.1: 45-55.

Tohir KA. 1991. Seuntai Pengetahuan Usaha Tani Indonesia. 1991, Rineka Citra. Jakarta.

Trade Map. 2014. List Of Patners for A Product Commercialized By Indonesia, Product: 3201901000 Gambier. 